\title{
Review of Thoreyella Spinola with the description of two new species from Brazil (Heteroptera, Pentatomidae)
}

\author{
Jorge Luiz Cabeleira Bernardes ${ }^{1}$, Cristiano Feldens Schwertner $^{2} \&$ Jocélia Grazia $^{1}$
}

\begin{abstract}
'Laboratório de Entomologia Sistemática, Departamento de Zoologia, Programa de Pós-Graduação em Biologia Animal, Universidade Federal do Rio Grande do Sul, Av. Bento Gonçalves 9500, Bloco IV, prédio 43435.2,91501-970 Porto Alegre-RS, Brazil. jorgecabeleira@gmail.com; jocelia@ufrgs.br ${ }^{2}$ Laboratório de Ecologia e Sistemática, Departamento de Ciências Biológicas, Programa de Pós-Graduação em Ecologia e Evolução, Universidade de São Paulo, Rua Prof. Artur Riedel 275, 09972-270 Diadema-SP, Brazil. schwertner@unifesp.br
\end{abstract}

\begin{abstract}
Review of Thoreyella Spinola with the description of two new species from Brazil (Heteroptera, Pentatomidae). Thoreyella Spinola is revised, with detailed descriptions of the four known species (T. brasiliensis Spinola, 1850, T. trinotata Berg, 1878, T. cornuta Berg, 1883 and, T. taurus Jensen-Haarup, 1931), and two new species from Brazil: T. maracaja sp. nov. (Minas Gerais, Santa Catarina, and Rio Grande do Sul states) and T. paraiba sp. nov. (Paraíba State). New geographical country and state/ province records are as follows: T. cornuta from Rio Grande do Sul; T. brasiliensis from Mato Grosso, Espírito Santo, Catamarca, and Córdoba; and T. trinotata from Brazil (Rio Grande do Sul). A key to all species is given.
\end{abstract}

KEYWORDS. Hemiptera; new taxa; Pentatominae; Procleticini; taxonomy.

RESUMO. Revisão de Thoreyella Spinola, com a descrição de duas novas espécies do Brasil (Heteroptera, Pentatomidae). Neste trabalho, o gênero Thoreyella Spinola é revisado com descrições detalhadas das quatro espécies conhecidas (T. brasiliensis Spinola, 1850, T. trinotata Berg, 1878, T. cornuta Berg, 1883 e T. taurus Jensen-Haarup, 1931) e duas novas espécies do Brasil: T. maracaja sp. nov. (estados de Mina Gerais, Santa Catarina e Rio Grande do Sul) e T. paraiba sp nov. (Estado da Paraíba). Novos registros de distribuição para países e estados/províncias são os seguintes: T. cornuta do Rio Grande do Sul; T. brasiliensis do Mato Grosso e Espírito Santo; Catamarca e Córdoba, e T. trinotata do Brasil. Uma chave dicotômica para as espécies é fornecida.

PALAVRAS-CHAVE. Hemiptera; novos táxons; Pentatominae; Procleticini, taxonomia.

Thoreyella was proposed by Spinola (1850) to include $T$. brasiliensis Spinola, 1850. Three species were added subsequently: T. trinotata Berg, 1878, T. cornuta Berg, 1883 and $T$. taurus Jensen-Haarup, 1931. Rolston (1984) revised Thoreyella and distinguished it from Odmalea Bergroth by: juga contiguous distally, ostiolar rugae slightly curved, coria costal angle reaching little or not at all beyond scutellum, and frena just surpassing basal third of scutellum; in Odmalea the juga converge distally, but are normally not contiguous, ostiolar rugae straight, coria costal angle far surpassing scutellum, and frena extending beyond middle of scutellum. Also, Rolston (1984) included Thoreyella in a group of seven American genera of Pentatomini, all of them with a ventral spine or tubercle anteriorly-projected at the base of the abdomen: Aleixus McDonald, Brepholoxa Van Duzee, Dendrocoris Bergroth, Odmalea, Rio Kirkaldy, Pseudobebaeus Distant, and Thoreyella. In a conspectus of Procleticini genera, Rider (1994) broadened the concept of the tribe, including Thoreyella and five of the six related genera mentioned by Rolston (1984), the excluded genus being Rio. Rider (1994) also related Thoreyella to Dendrocoris and Odmalea; he distinguished Thoreyella from Dendrocoris by the apical spine of the femur in the former; to separate Thoreyella from Odmalea he followed Rolston (1984).

Bernardes et al. (2009), in a cladistic analysis of Thoreyella and related genera, established the monophyly of the genus, including six species and supported by nine synapomorphies: humeral angles not emarginated; anterolateral margins of pronotum in an obtuse angle; lateral margins of scutellum straight; scutellum reaching or slightly surpassing the connexival segment VI; apex of femur with an acute spine; apex of the abdominal spine curved; sutural margins of the processes of the ventral rim of pygophore anteriorly convex and posteriorly parallel; posterolateral angles of the pygophore concave; anterior portion of the vesicular area of the ductus receptaculi strongly sclerotized and usually delimited by a constriction. Among Procleticini, Thoreyella has a sister-group relationship with the monophyletic clade (Neoderoploa Pennington $+($ Lobepomis Berg + Procleticus Berg) $)$.

In this paper, we review the genus Thoreyella, diagnose and redescribe all the known taxa. The two new species listed in Bernardes et al. (2009) as Thoreyella sp. nov. 1 e T. sp. nov. 2 are here described as Thoreyella maracaja sp. nov. and Thoreyella paraiba sp. nov, respectively. Also, new taxonomic arrangements, and a key for the species of Thoreyella are proposed.

\section{MATERIAL AND METHODS}

One hundred and thirty five specimens were studied from the following collections (curator in parenthesis): CERSC Coleção Entomológica de Referência da Universidade do 
Extremo Sul Catarinense, Criciúma/SC, Brazil (B. HarterMarques); DZUP - Coleção Entomológica Pe. Jesus Santiago Moure, Curitiba/PR, Brazil (L. Marinoni); FIOC - Fundação Oswaldo Cruz, Rio de Janeiro/RJ, Brazil (J. Costa); MACN Museo Argentino de Ciencias Naturales Bernardino Rivadavia, Buenos Aires, Argentina (A. Roig Alsina); MLPA - Facultad de Ciências Naturales y Museo, La Plata, Argentina (M. C. Coscarón); MNRJ - Museu Nacional do Rio de Janeiro, Rio de Janeiro/RJ, Brazil (L. Costa); MRSN - Museo Regionale di Scienze Naturali, Torino, Italy (P. L. Scaramozzino); MZSP - Museu de Zoologia da Universidade de São Paulo, São Paulo/ SP, Brazil (C. Campaner); RMNH - Nationaal Natuurhistorische Museum, Leiden, Netherlands (R. de Vries); UFRRJ Coleção Costa Lima, Seropédica/RJ, Brazil (A. F. de Lima); UFRG - Coleção do Departamento de Zoologia da Universidade Federal do Rio Grande do Sul, Porto Alegre/RS, Brazil (J. Grazia); ZMUC - Zoological Museum, University of Copenhagen, Copenhagen, Denmark; (N. P. Kristensen). Typematerial of all species was examined.

The classification of the genus (Fig. 1) follows Bernardes et al. (2009). The terminology of the genitalia was based on Dupuis (1970), Schaefer (1977) and Davidová-Vilímová \& McPherson (1991), with modifications (Bernardes et al. 2009).

Seventeen morphological parameters were obtained and are expressed in millimeters (Tab. 1); mean, range (maximum and minimum) and standard deviation are given for each measurement, when applicable. Illustrations were made with a camera lucida connected to a stereomicroscope, digitalized, and treated in Adobe ${ }^{\circledR}$ Photoshop ${ }^{\circledR}$ CS3. Images were obtained with a digital camera connected to a stereomicro-

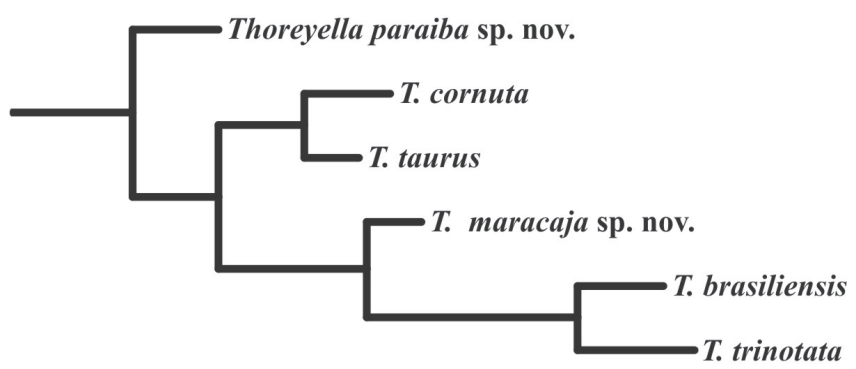

Fig. 1. Cladogram of relationships among species of Thoreyella proposed by Bernardes et al. (2009).

scope. Dissections of internal genitalia of males or females were made only when more than one specimen were available for study. Symbols used to express antennal segments proportion are: "<" shorter; ">" longer; " $\geqslant$ " longer or even; " " subequal.

\section{RESULTS AND DISCUSSION}

\section{Thoreyella Spinola}

(Figs. 2-71)

Thoreyella Spinola, 1850: 79-80 (descr.), 1852: 119-120 (descr.); Stål 1872: 45 (n. syn.); Kirkaldy 1909: 137 (cat.); Jensen-Haarup 1931: 319-320 (descr., key spp.); Pirán 1957: 67-68 (key spp.); Rolston 1978: 20, (key gen.); Rolston et al. 1980: (key); Rolston 1984: 826-834 (rev.); Rider 1994: 193-221 (rev., key gen.); Grazia et al. 1999: 109 (list); Grazia \& Schwertner 2008: 234 (list); Bernardes et al. 2009: 1-23 (phylogeny, classification, distr.); Grazia \& Schwertner 2011: 12 (list).

Uditta Stål, 1860: 23 (descr.), 1867: 531 (key).

Table I. Morphological measurements of species of Thoreyella Spinola, in millimeters. (* maximum and minimum; ** average \pm standard deviation (maximum and minimum); I, II, III, IV, V = Antennal segments length; AW = abdominal width; HL = head length; HW = head width; ID = interocular distance $\mathrm{PaH}=$ pronotum anterior height; $\mathrm{PL}=$ pronotum length $\mathrm{PpH}=$ pronotum posterior height; $\mathrm{PW}=$ pronotum width; $\mathrm{RL}=$ rostrum length; $\mathrm{SL}=$ scutellum length; SW = scutellum width; TL = total length.

\begin{tabular}{|c|c|c|c|c|c|c|}
\hline & $\begin{array}{c}\text { T. paraiba } \\
(\mathrm{n}=2)^{*}\end{array}$ & $\begin{array}{l}\text { T. cornuta } \\
(\mathrm{n}=5)^{* *}\end{array}$ & $\begin{array}{l}\text { T. taurus } \\
(\mathrm{n}=1)\end{array}$ & $\begin{array}{l}\text { T. maracaja } \\
(\mathrm{n}=7)^{* *}\end{array}$ & $\begin{array}{l}\text { T. brasiliensis } \\
(\mathrm{n}=10)^{* *}\end{array}$ & $\begin{array}{l}\text { T. trinotata } \\
(\mathrm{n}=10)^{* *}\end{array}$ \\
\hline TL & $6.56-5.18$ & $6.32 \pm 0.17(6.55-6.12)$ & 6.64 & $5.75 \pm 0.5(6.08-5.18)$ & $6.3 \pm 1(7.45-5.18)$ & $6.45 \pm 0.62(7.29-5.75)$ \\
\hline HL & $1.54-1.34$ & $1.44 \pm 0.04(1.5-1.4)$ & 1.6 & $1.33 \pm 0.03(1.36-1.28)$ & $1.36 \pm 0.15(1.56-1.16)$ & $1.36 \pm 0.1(1.48-1.2)$ \\
\hline HW & $1.62-1.42$ & $1.54 \pm 0.01(1.56-1.54)$ & 1.58 & $1.56 \pm 0.06(1.62-1.48)$ & $1.47 \pm 0.12(1.68-1.32)$ & $1.5 \pm 0.07(1.62-1.36)$ \\
\hline ID & $1-0.88$ & $0.98 \pm 0.01(1-0.96)$ & 0.98 & $1.01 \pm 0.04(1.04-0.96)$ & $0.98 \pm 0.09(1.11-0.88)$ & $0.93 \pm 0.07(1.04-0.8)$ \\
\hline I & $0.34-0.28$ & $0.32 \pm 0.01(0.34-0.3)$ & 0.36 & 0.28 & $0.29 \pm 0.02(0.32-0.26)$ & $0.30 \pm 0.01(0.32-0.28)$ \\
\hline II & $0.46-0.42$ & $0.51 \pm 0.01(0.52-0.5)$ & 0.54 & $0.42 \pm 0.03(0.46-0.38)$ & $0.35 \pm 0.04(0.42-0.3)$ & $0.43 \pm 0.05(0.5-0.36)$ \\
\hline III & $0.44-0.4$ & $0.46 \pm 0.02(0.5-0.44)$ & 0.48 & $0.5 \pm 0.03(0.54-0.46)$ & $0.42 \pm 0.06(0.5-0.34)$ & $0.42 \pm 0.05(0.52-0.36)$ \\
\hline IV & $0.56-0.54$ & $0.54 \pm 0.04(0.6-0.52)$ & 0.62 & $0.66 \pm 0.04(0.7-0.62)$ & $0.48 \pm 0.03(0.54-0.44)$ & $0.50 \pm 0.04(0.56-0.42)$ \\
\hline $\mathrm{V}$ & 0.72 & $0.71 \pm 0.03(0.76-0.68)$ & 0.82 & $0.87 \pm 0.04(0.88-0.8)$ & $0.66 \pm 0.05(0.74-0.62)$ & $0.66 \pm 0.04(0.74-0.6)$ \\
\hline PL & $2.04-1.64$ & $1.95 \pm 0.1(2.04-1.84)$ & 1.96 & $1.83 \pm 0.12(1.96-1.68)$ & $1.67 \pm 0.23(1.96-1.36)$ & $1.75 \pm 0.14(2-1.48)$ \\
\hline PW & $5.75-4.69$ & $5.9 \pm 0.2(6.15-5.67)$ & 5.42 & $5.22 \pm 0.23(5.50-4.61)$ & $4.43 \pm 0.6(5.18-3.64)$ & $4.94 \pm 0.8(6.15-3.8)$ \\
\hline SL & $3.2-2.48$ & $2.92 \pm 0.15(3.12-2.8)$ & 2.96 & $2.76 \pm 0.26(3-2.44)$ & $2.96 \pm 0.5(3.52-2.4)$ & $3.25 \pm 0.3(3.64-2.68)$ \\
\hline SW & $3.12-2.4$ & $2.87 \pm 0.07(2.96-2.8)$ & 3 & $2.78 \pm 0.23(3-2.52)$ & $2.6 \pm 0.4(3.16-2.16)$ & $2.71 \pm 0.23(3.04-2.32)$ \\
\hline $\mathrm{PaH}$ & $1.2-0.96$ & $1.11 \pm 0.06(1.2-1.08)$ & 1 & $1 \pm 0.05(1.04-0.92)$ & $0.96 \pm 0.12(1.08-0.8)$ & $1.01 \pm 0.04(1.08-0.96)$ \\
\hline $\mathrm{PpH}$ & $2.48-2.04$ & $2.19 \pm 0.1(2.32-2.12)$ & 2.24 & $2 \pm 0.18(2.16-1.72)$ & $1.81 \pm 0.27(2.16-1.48)$ & $1.94 \pm 0.15(2.16-1.72)$ \\
\hline AW & $4.92-3.92$ & $4.47 \pm 0.1(4.56-4.4)$ & 4.48 & $4.05 \pm 0.33(4.36-3.64)$ & $3.96 \pm 0.57(4.64-3.24)$ & $4.13 \pm 0.4(4.68-3.52)$ \\
\hline RL & $2.24-2.06$ & $2.26 \pm 0.1(2.4-2.2)$ & 2.4 & $1.91 \pm 0.04(1.96-1.88)$ & $1.91 \pm 0.2(2.2-1.74)$ & $1.86 \pm 0.2(2.38-1.86)$ \\
\hline
\end{tabular}



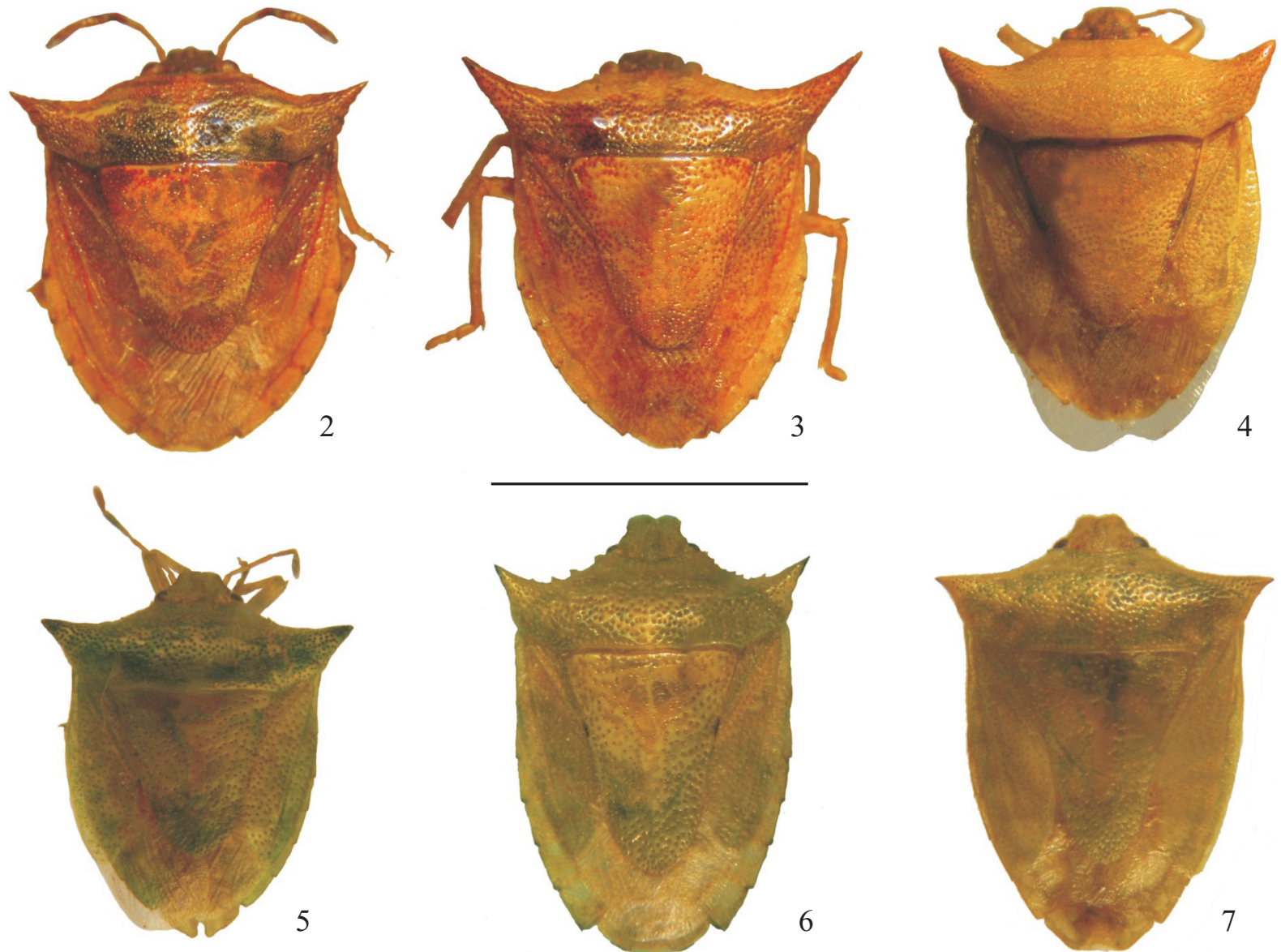

Figs. 2-7. Thoreyella species: 2, T. paraiba $\mathbf{s p . ~ n o v . ; ~ 3 , ~ T . ~ c o r n u t a ; ~ 4 , ~ T . ~ t a u r u s ; ~ 5 , ~ T . ~ m a r a c a j a ~} \mathbf{s p .}$ nov.; 6, T. brasiliensis; 7 , T. trinotata. $($ Scale $=5$ mm).

Diagnosis. Members of Thoreyella can be recognized by the following characters (Rider 1994; Bernardes et al. 2009): juga usually contiguous anteriorly, lateral jugal margins sinuous (Figs. 12-13); antennal segments II and III subequal in length; rostrum reaching between mesocoxae; humeral angles rounded to spinose, but never emarginated (Figs. 2-8); anterolateral margins of pronotum in an obtuse angle (Figs. 2-7); scutellum somewhat spatulate (Figs. 2-8), reaching or slightly surpassing the connexival segment VI, lateral margins straight, and each basal angle lacking fovea (Fig. 9); apex of scutellum rounded; thoracic sterna flat; apex of femur with an acute spine (Fig. 10); apex of abdominal spine curved (Fig. 11); sutural margins of processes of the ventral rim of pygophore anteriorly convex and posteriorly parallel (Fig. 14); posterolateral angles of the pygophore concave (Fig. 14); anterior portion of the vesicular area of the ductus receptaculi strongly sclerotized and usually delimited by a constriction (Figs. 69-71).

Redescription. Color varying from olive green to medium brown; preserved specimens become yellowish-brown (Figs. 2-7). Juga outlined or not in black (Fig. 13). Antenniferous tubercles with a dorsal black dot. Scutellum uniform in color, basal angles and apex of clavus each with a small black spot. Membrane of hemelytra transparent. Propleura with a black macula just behind each anterolateral angles, united to an- other black macula at its margins by a curved, thin black line, sometimes faded or absent. Black macula at posterolateral angles of mesoepimerum sometimes present. Legs usually concolorous with body, sometimes darker, with black dots. Connexivum and ventral abdomen concolorous with dorsal surface. Posterolateral angles of urosternites, spiracles, and trichobothria tubercles, black or concolorous with dorsal surface. Ovate or elongate in shape (Figs. 2-7). Head wider than long (Figs. 12-13). Width of head less than the width of pronotum anteriorly. Juga juxtaposed before tylus, lateral margins sinuous or straight. First antennal segment not surpassing head apex. Antennal segments: I $<$ II $\geqslant$ III $<$ IV $<$ V. Elliptical cicatrices between ocelli and eyes, with irregular texture and without punctures (Figs. 12-13). Ocelli sometimes on tubercles. Buccula sinuous, apical tooth developed, posterior border lobate, usually projecting toward the prosternum. First rostral segment not extending beyond apex of bucculae. Rostrum attaining metacoxae. Anterior half of pronotum sloping (Figs. 8, 11). Anterolateral angles of pronotum spined. Anterolateral margins of pronotum concave or rectilinear, smooth or dentate; tangential lines to dorsal and ventral surfaces forming an obtuse angle. Humeral angles (Fig. 8) in conical spines, not emarginated. Pronotum width at posterior margin three times the head width. Scutel- 
lum longer than wide (Fig. 9), lateral margins straight, apex rounded, attaining or surpassing VI connexival segment, often surpassing apex of corium. Frenum reaching or surpassing basal third of scutellum (Fig. 9). Ostiolar ruga slightly curved anteriorly, apex acuminate, attaining more than half of metapleurum. Evaporative area of mesopleurum occupying the mesoepimerum, not attaining the anterior margin of mesopleurum. Evaporative area of metapleurum often not attaining the metaepimerum pseudo-suture. Apex of femur with an acute spine usually more developed in posterior legs; tibia dorsally flattened or sulcate. Hairs denser in tibia than femur, specially near tarsus. Abdomen strongly convex ventrally. Abdominal spine subcylindrical, apex curved, always surpassing metacoxae (Fig. 11). Spiracles placed on calli or not. Trichobothria placed mesially the spiracles line. Posterior margin of VII urosternite strongly concave on females, middle third obscuring most of the gonocoxites 8, lateral thirds sinuous or straight (Fig. 62).

Male genitalia. Pygophore (Figs. 14-33) subquadrangular; ventral rim projected posteriorly in a complex process. Dorsal rim (Fig. 14) widely excavate, semicircular, lateral thirds reaching posterolateral angles, causing a reduction on dorsal wall of pygophore. Ventral wall (Fig. 19) wide, with more than twice the length of the dorsal wall. Ventral rim processes (Fig. 14) in $1+1$ triangular flaps bending obliquely dorsad into the genital cup, forming a semi tube which sutural margins are parallel at least on posterior third. Genital cup open posterodorsally. Posterolateral angles of pygophore concave (Fig. 14). Superior process of genital cup triangular, partially obscured by the dorsal rim fold. Parameres (Figs. 34-49) glabrous, geniculate, basal portion laterally flat and apical portion (head of parameres) bi- or trilobate placed perpendicularly to the pygophore axis. Segment X (Fig. 14) cylindric or ogive-like, also perpendicular to the pygophore axis. Articulatory apparatus with a wide basal plate, processus capitati almost reaching apex of phallotheca. Phallotheca (Figs. 50-61) dorsally convex and ventrally concave; processus phallothecae (Fig. 50) pyramidal. Conjunctiva (Fig. 50) with $1+1$ triangular membranous lobes. Vesica (Fig. 50) curved, longer than conjunctiva or not.

Female genitalia (Figs. 62-71). Laterotergites 8 (Fig. 62) cuneiform, basally concave or flat; ventral band connecting the laterotergites 8 not obscured by laterotergites 9 . Gonocoxites 8 (Fig. 62) reduced, triangular or obovate, with convex surface, and a cusp variable in length; sutural margins not juxtaposed, apices divergent exposing the gonapophyses 8. Segment X (Fig. 62) trapezoidal, apical margin straight. Capsula seminalis (Fig. 68) globose, apical process present. Pars intermedialis (Fig. 68) shorter than capsula seminalis; annular flanges subequal in diameter. Anterior portion of the vesicular area of the ductus receptaculi strongly sclerotized, curved, measuring one third of the total length of the vesicular area, usually delimited by a constriction.

Comments. Thoreyella shares the unique characteristics of the Procleticini (Rider 1994; Bernardes et al. 2009). The genus was related to Dendrocoris and Odmalea (Rolston 1978; 1984; Rider 1994), although evidence supporting the hypoth- esis was poorly discussed. Based on a cladistic analysis of 38 characters, Bernardes et al. (2009) established the relationship of Thoreyella with Dendrocoris, Lobepomis, Neoderoploa, Procleticus and Terania Pirán, all of which share a spatulate juga, a unique derived characteristic among the Procleticini. The monophyly of the genus was also supported (Bernardes et al. 2009) based on nine synapomorpies. Just one of the diagnostic characters of Thoreyella pointed out by Rolston (1978, 1984) was confirmed as a synapomorphy (apex of abdominal spine curved). The ostiolar rugae acuminate, also listed as diagnostic for Thoreyella (Rolston 1978), is shared with Lobepomis, Neoderoploa, Procleticus and Terania (Bernardes et al. 2009). These monotypic genera are grouped in a clade, which is the sister group of Thoreyella (Bernardes et al. 2009). The other two characteristics mentioned as diagnostic to Thoreyella (Rolston 1978; 1984; Rider 1994) are homoplastic among the species of the genus or showed ambiguous reconstruction in the analysis (Bernardes et al. 2009).

Distribution. Thoreyella is restricted to the Chaco and Paraná subregions of the Neotropical region. Comments on the distribution of the species and the biogeography of Thoreyella can be found in Bernardes et al. (2009).

\section{Key to the species of Thoreyella.}

1. Frenum reaching basal third of the scutellum (Figs. 6, 7, 9)

1'. Frenum reaching middle of the scutellum (Figs. 2-5) . 3

2. Anterolateral margins of pronotum with three or more acute teeth (Fig. 6); juga strongly sinuous before the eyes; spiracles in a conspicuous white callus

Thoreyella brasiliensis Spinola, 1850

2'. Anterolateral margins of pronotum smooth (Fig. 7); juga scarcely sinuous before the eyes; spiracles without callus Thoreyella trinotata Berg, 1878

3. Punctures of head concolorous with surface of head; lateral margins of juga outlined in black (Fig. 13); spiracular peritremes concolorous with surface of abdomen (Fig. 11); trichobothria tubercles blackThoreyella maracaja sp. nov.

3'. Punctures of head black distinctly darker than head surface; lateral margins of juga not black; spiracular peritremes black; trichobothria tubercles concolorous with surface of abdomen ..................................................... 4

4. Pronotal disc smooth without transverse callus (Fig. 4); pronotum uniform in color (Fig. 4)

Thoreyella taurus Jensen-Haruup, 1931

4'. Pronotal disc divided by a transverse callus; posterior portion of pronotum darker than anterior portion ......... 5

5. Humeral angles with acute spines directed laterad (Fig. 2 ); spines at apex of femur shorter than half femur width Thoreyella paraiba $\mathbf{s p . ~ n o v . ~}$

5'. Humeral angles with acute, robust, and well developed spines (Figs. 3, 8) directed anterodorsad (Fig. 8); spines at apex of femur longer than half femur width

Thoreyella cornuta Berg, 1883 


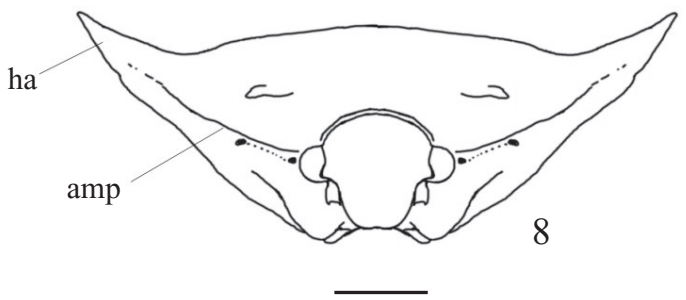

$\mathrm{cs}$
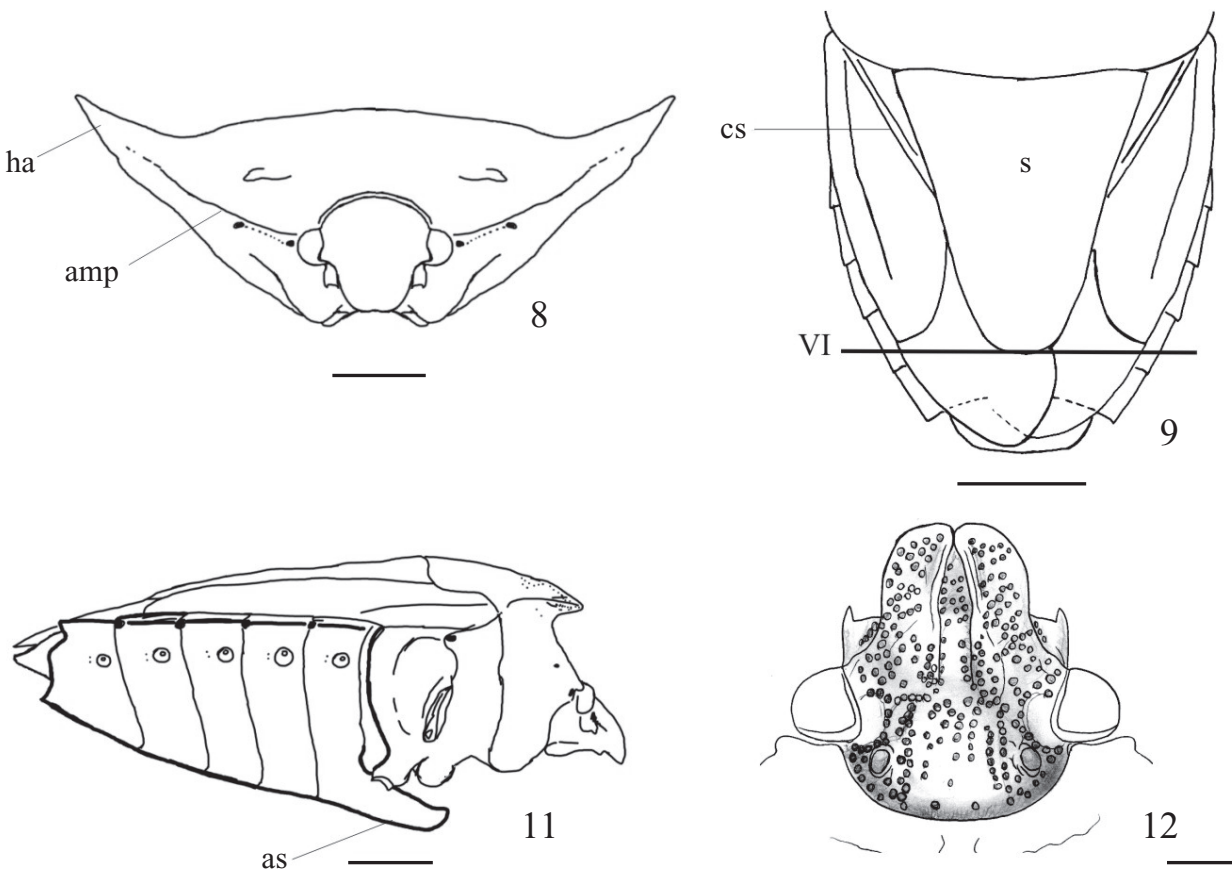

12
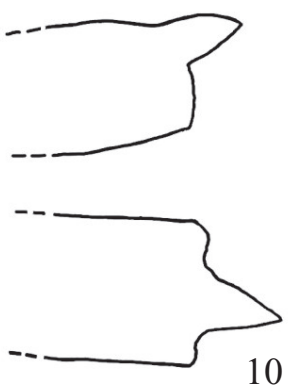

10

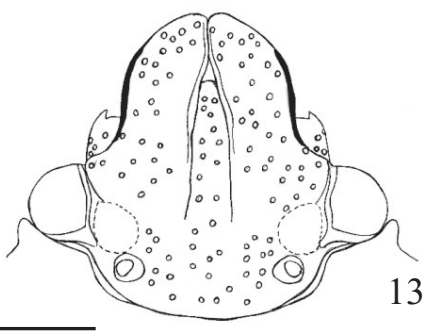

Figs. 8-13. 8, Thoreyella cornuta: head and pronotum; 9, T. brasiliensis: scutellum, hemelythrum and abdomen; 10 and 11, T. maracaja sp. nov.: 10, spine of apex of femur; 11, lateral view of body; 12, T. paraiba sp. nov.: head, dorsal view; 13, T. maracaja sp. nov.: head, dorsal view. amp, antero-lateral margin of pronotum; as, abdominal spine; cs, claval suture; ha, humeral angle; s , scutellum; VI, sixth abdominal segment. Scale: $8-9$, 11-13=1 mm, 10 = 0.5 mm.

Thoreyella paraiba sp. nov.

(Figs. 2, 12, 14, 19, 24, 29, 62, Table I)

Thoreyella sp. nov. 2 in Bernardes et al., 2009: 2-4, 6, 11, 14-15, 17, 19-21.

Etymology. Name allusive to the type-locality.

Diagnosis. Head darker than the rest of the body. Juga short with one third the length of buccula. Punctures of head black, distinctly darker than head surface (Fig. 12). Pronotal disc strongly convex medially. Humeral angles in short spines directed laterad. Scutellum basal angles with reddish brown or dark brown punctures. Spine at apex of femur short. Process of the ventral rim of pygophore (Fig. 14) with $2+2$ teeth on posterior margin, the former tooth acute, obscuring the second. Parameres with a clear strip between the dark lobes of apical portion. Gonocoxites 8 obovate with a short cusp.

Description. General color yellowish-brown (Fig. 2), punctures concolorous with body surface or dark brown, sometimes reddish-brown. Head dark brown, with dark punctures (Fig. 12); tylus and median margins of juga lighter in color than front and vertex. Antenniferous tubercles with some black punctures and a castaneous stripe dorsally which extends along margins of juga. Humeral angles with dark punctures on posterolateral margins. Pronotal disc yellowish-brown on males; reddish-brown anterior to transverse callus and dark-brown after callus on females (Fig. 2). Basal angles of scutellum with red or dark brown punctures. Propleura with two dark macula; mesopleura without macula. Sternum black on females; castaneous on males. Legs darker than the venter. Spiracles with castaneous ring; trichobothria tubercles concolorous with the body surface.

Ovate. Head (Fig. 12): juga short, measuring one third the length of buccula in lateral view; frons and vertex swollen; cicatrices adjacent to eyes, occupying almost half the length of eyes; ocelli directed anteriorly. Antennal segments: $\mathrm{I}<\mathrm{II} \sim \mathrm{III}<\mathrm{IV}<\mathrm{V}$. Pronotal disc strongly sloping, medially convex; transverse callus sinuous, reaching humeral angles; longitudinal calloused line ending in a callus between cicatrices. Humeral angles in short acute spines dorsolaterally directed. Scutellum divided by apices of claval suture in two equally portions, basal half convex, basal angles slightly concave. Opening of odoriferous glands small; ostiolar ruga not reaching the middle of metapleura, curved to mesopleura; evaporative area reduced, not extending along ostiolar ruga. Spines at apices of femur acute, short, less than half the femur width, forming an angle with more than $45^{\circ}$ but less than $90^{\circ}$. Abdominal spine short, thin, attaining metacoxae. Spiracles not placed on a callus. Posterior margin of segment VII in females with lateral thirds sinuous, the convex portion obscuring basal concavity of laterotergites 8 .

Male genitalia (Figs. 14, 19, 24, 29). Pygophore. Process of the ventral rim (Fig. 14, vrp) with $2+2$ teeth on posterior margin, the former tooth triangular, acute, obscuring the second pair, with less than half the size of the former pair. Posterolateral angles (Fig. 14, pla) strongly angulate, concavity occupying almost half width of the ventral rim process. Sutural margins of ventral rim processes posteriorly parallel, anteriorly sinuous. Median extensions of ventral rim processes slightly extended in lateral view. Posterior margin of 
the infolding of ventral rim with a median sulcus in "V", margins swollen (Fig. 19, ivr). Parameres with apical portion bilobate; lobes clearly separate by a non-pigmented stripe.

Female genitalia (Fig. 62). Laterotergites 8 (Fig. 62, la8) concave at base and flat at apex, sutural margin swollen. Gonocoxites 8 (Fig. 62, gc8) obovate with a moderate cusp, similar to T. maracaja sp. nov. (Fig. 65). Laterotergites 9 (Fig. 62 , la9) slightly surpassing segment X, lateral half scarcely elevate, not forming a carina, median half flat; apex slightly emarginated, median margins slightly concave. Gonapophyses 8 (Fig. 62, g8) with posterior margin elevated at middle. Segment $\mathrm{X}$ longer than wide with transverse grooves.

Measurements in Table I.

Distribution. BRAZIL: Paraíba.

Material examined. Holotype male. BRAZIL. Paraíba: Soledade, Juazeirinho, 8.VII.1956, A. G. A. Silva col., Campos Seabra Collection (MNRJ). Paratype Female. BRASIL. Paraíba: Soledade, Juazeirinho, 8.VII.1956, A. G. A. Silva col., Campos Seabra Collection (UFRG).

Comments. T. paraiba sp. nov. shares with $T$. cornuta the homoplastic character juga short with one third the length of buccula. Can be distinguished by the humeral angles less developed and directed laterad, shorter spine at apex of femur, and the presence of a median callus between cicatrices of pronotum. These species also share, in females, the gonocoxites 8 with a small cusp, and in males, the greater and more acute triangular teeth of the ventral rim of pygophore processes.

\section{Thoreyella cornuta Berg, 1883}

(Figs. 3, 15, 20, 25, 30, 34-37, 50-52, 63, 68, Table I)

Thoreyella cornuta Berg, 1883: 215 (descr.); Berg 1884: 31 (descr.); Kirkaldy 1909: 137 (cat.); Pirán 1956: 31 (citation); Rolston, 1984: 830 (Lectotype des.); Rider 1994: 218 (citation); Coscarón \& Grazia 1996: 109 (cat.); Grazia \& Schwertner 2008: 234 (list); Bernardes et al. 2009: 3, 4, 8-11, 13-16, 18, 21, 22 (classification, distr., fig.).

Diagnosis. Head darker than rest of body. Juga short, measuring one third the length of buccula in lateral view. Humeral angles developed in long spines directed anterodorsally. Pronotal disc divided by a transverse callus, anterior half lighter in color. Sternum black. Spine at apex of femur long and acute, obliquely directed. Spiracles black. Processes of ventral rim of pygophore with $2+2$ teeth on posterior margin, the former tooth triangular, obtuse, second pair with less than half the length and partially covered by the first. Posterolateral angles not excavate, concavity occupying almost one third of the ventral rim processes width. Gonocoxites 8 with a well-developed cusp.

Redescription. General color dark brown to green, dorsum darker than venter. Head darker than the rest of the body, densely punctured with black. Cicatrices between eyes and ocelli elliptical, clear than the remainder of the head. Rare punctures on antenniferous tubercles. Pronotal disc yellowish-brown before transverse callus, darker after callus. Base
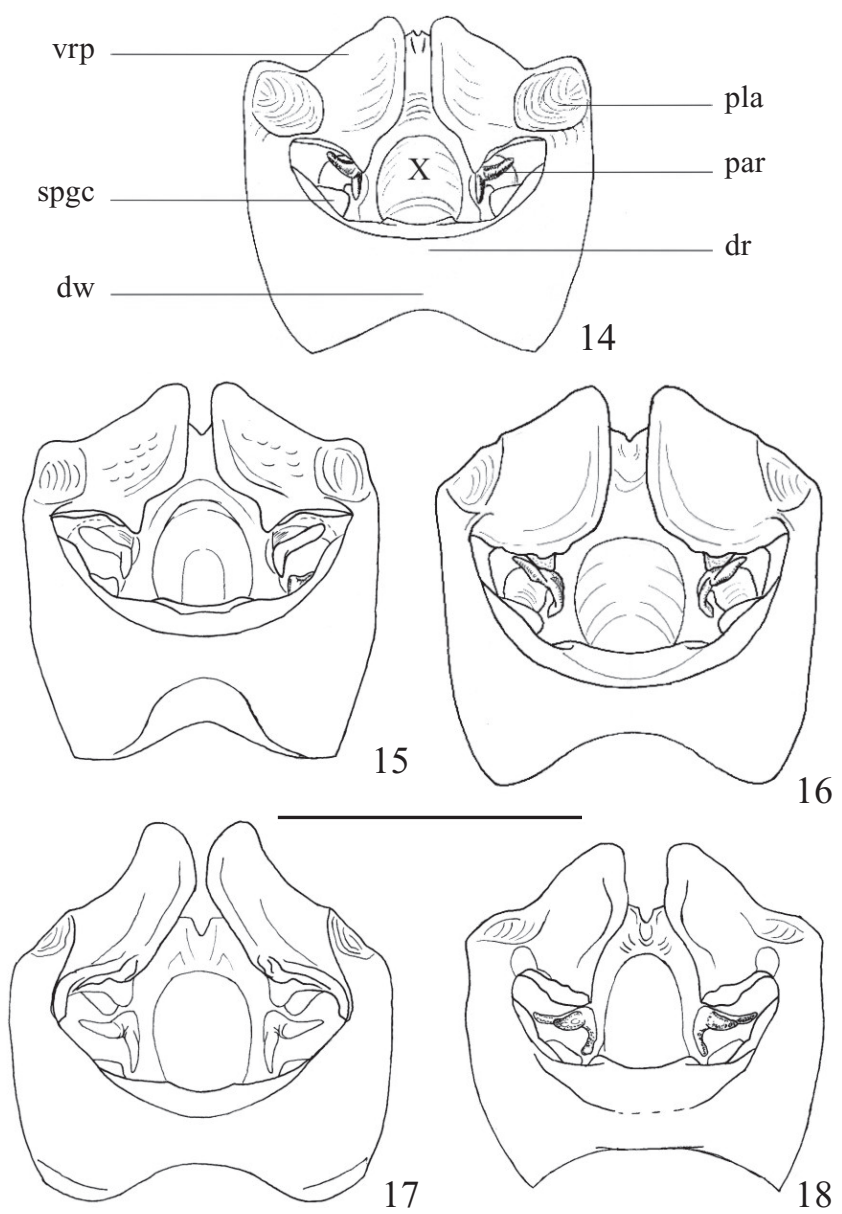

Figs. 14-18. Pygophore, dorsal view: 14, Thoreyella paraiba sp. nov.; 15, T. cornuta; 16, T. maracaja sp. nov.; 17, T. brasiliensis; 18 , T. trinotata; dr, dorsal rim; dw, dorsal wall; par, paramere; pla, postero-lateral angle; spgc, superior process of genital cup; vrp, ventral rim process; $\mathrm{X}$, tenth segment. Scale $=1 \mathrm{~mm}$

of scutellum with ferrugineous punctures; apices of clavus with a small black macula. Propleura with two black macula. Mesoepimerum with a black macula at lateroposterior margin. Sternum black. Spiracles black.

Ovate. Juga measuring one third the length of buccula in lateral view, juxtaposed, slightly concave at apex, lateral margins subparallel; apex of head truncate. Frons and vertex swollen. Anterior tooth of buccula directed laterad. Antennal segments: $\mathrm{I}<\mathrm{II} \geqslant \mathrm{III}<\mathrm{IV}<\mathrm{V}$. Humeral angles robust, directed anterodorsally; transverse callus of pronotum sinuous, reaching humeral angles. Scutellum triangular, almost as wide as long, attaining abdominal segment VI. Corium slightly surpassing scutellum, also attaining abdominal segment VI. Spines at apex of femur acute, longer than half width of femur, directed obliquely, more developed on posterior legs. Abdominal spine attaining second coxae. Connexivum more exposed on females.

Male genitalia (Figs. 15, 20, 25, 30, 34-37, 50-52). Pygophore. Process of the ventral rim with $2+2$ teeth on posterior margin, the former tooth triangular, obtuse, obscuring 

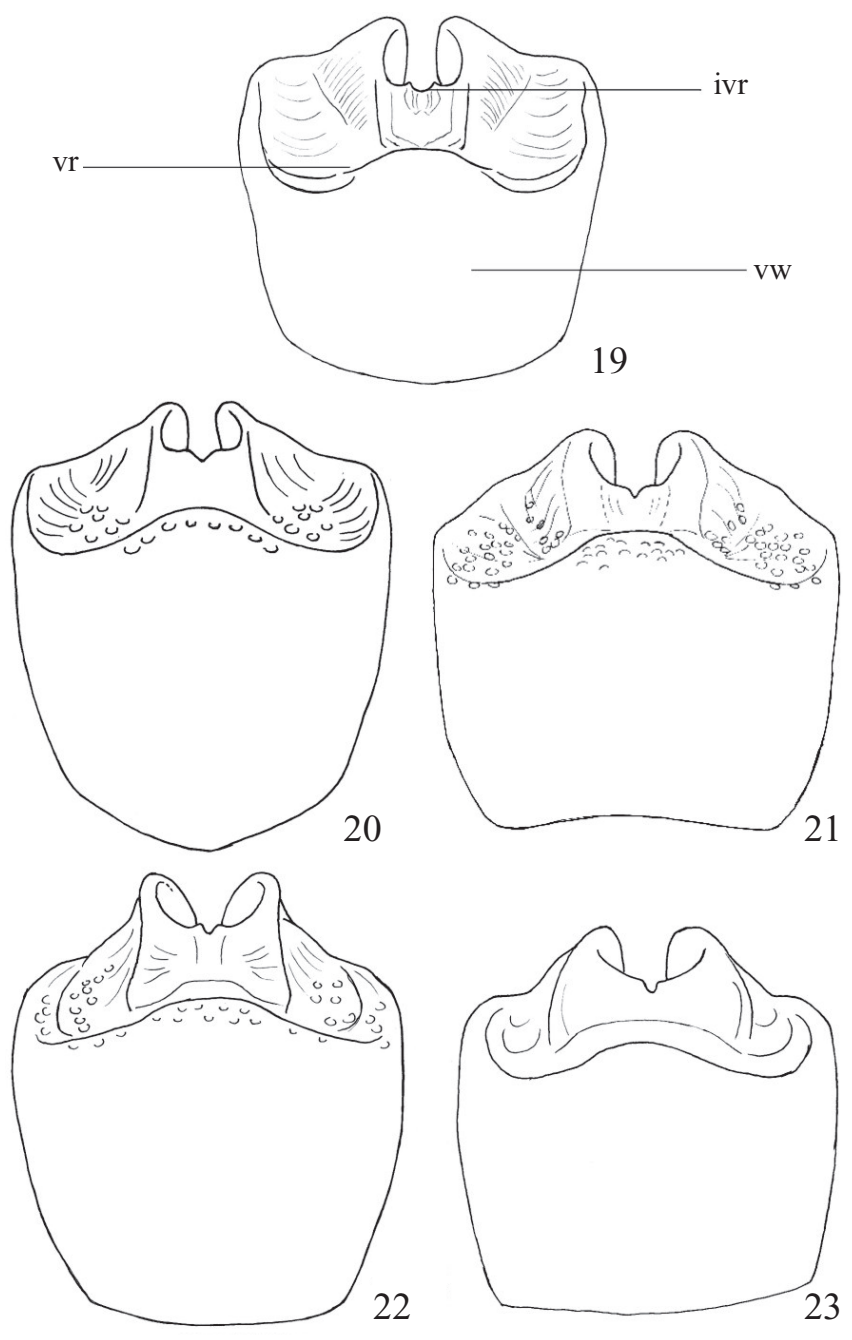

Figs. 19-23. Pygophore, ventral view: 19, Thoreyella paraiba sp. nov.; 20, T. cornuta; 21, T. maracaja sp. nov.; 22, T. brasiliensis; 23, T. trinotata. vr, ventral rim; ivr, infolding of ventral rim; vw, ventral wall. Scale $=1 \mathrm{~mm}$.

the second pair, with less than half the size of the former pair. Posterolateral angles angulated, concavity occupying almost one third of the width of the ventral rim process. Sutural margins of ventral rim processes posteriorly parallel. Posterior margin of the infolding of ventral rim in open "V". Parameres (Figs. 34-37) with apical portion bilobate; dorsal width of apical portion (Fig. 34, ap) with twice the width of basal portion (Fig. 34, bp). Phallotheca (Fig. 50, ph) with posteroventral opening. Processus phallothecae (Fig. 50, pp) pyramidal. Vesica (Fig. 50, v) as long as conjunctiva (Fig. 50, c). Secondary gonopore (Fig. 50, sg) opening between conjunctival lobes.

Female genitalia (Figs. 63, 68). Laterotergites 8 concave at base and flat at apex. Gonocoxites 8 obovate, sutural margins convex and forming a stout cusp; posterior margins sinuous, concavity adjacent to the cusp. Laterotergites 9 with lateral half moderately elevate, forming a convex carina, median half flat; apical third concave, apex emarginated. Capsula seminalis process (Fig. 68, csp) slightly curved, with one and half times longer than the capsula length (Fig. 68, cs). Posterior annular flange larger than anterior annular flange. Anterior portion of vesicular area curved more sclerotized than the posterior portion; no constriction between these portions (Fig. 68, apva).

Measurements in Table I.

Distribution. BRAZIL: Mato Grosso and Rio Grande do Sul [new record]; ARGENTINA: Entre Rios and Buenos Aires; URUGUAY.

Material examined. Holotype male, with the labels: a) Typus, b) Banda Oriental, c) 1409, d) Lectotype (top) Paralectotype Thoreyella cornuta Berg, (MLPA) [male and female mounted in the same pin]; Paralectotypes male, 2 females: a) Typus, b) Banda Oriental, c) 1409, (MLPA). BRAZIL. Rio Grande do Sul: Viamão, Morro do Côco, 19.II.1962, 2 females (UFRG);Viamão, Belém Novo, 7.I.1985, M. Sobral col., male (UFRG). URUGUAY. Banda Oriental, (31), "Cum typo comparat", Ex. Coll. Bergiana, male (MACN). ARGENTINA. Buenos Aires: ${ }^{\circ} 4640$, without data, male (MACN); Buenos Aires, San Fernando, without data, ${ }^{\circ} 28955$, 2 males (MACN).

Comments. This species shares with T. taurus the black sternum in both sexes, a unique character among species of Thoreyella, and with T. paraiba sp. nov. the juga three times shorter than buccula. Thoreyella cornuta, like T. taurus and T. paraiba sp. nov., can be distinguished from the remaining species by the head darker than the body.

\section{Thoreyella taurus Jensen-Haarup, 1931}

(Figs. 4, 64, Table I)

Thoreyella taurus Jensen-Haarup, 1931: 321 (descr.); Rolston 1984: 830 831 (descr.); Rider 1994: 218 (citation); Grazia et. al. 1999: 109 (cat.); Bernardes et al. 2009: 2-4, 7, 8, 10-12, 14, 15, 17, 18, 20-22 (classification, distr., fig.).

Diagnosis. Head darker than rest of body. Pronotal disc uniform in color. Humeral angles red, directed anteroventrally. Corium obscuring connexival segments; hemelytra surpassing apex of abdomen. Spiracles black. Genital plates flat; gonocoxites 8 obovate, without cusp. Band uniting the laterotergites 8 ventrally two times the segment $\mathrm{X}$ width.

Redescription. General color yellowish-brown. Head darker than the body because the concentration of black punctures on its base. Antenniferous tubercles with black punctures on dorsal side. Humeral angles red, with black punctures and a black line on posterolateral margins. Scutellum uniform in color, with reddish-brown punctures on posterior half. Propleurum with two black macula. Sternum dark. Legs concolorous with the body. Spines at apices of femur apically black. Abdomen ventrally without macula. Posterolateral angles of urosternites with black apex. Punctures concolorous with the body, abundant on abdominal surface, less frequent along mid line. Spiracles black.

Ovate. Head with frons and vertex swollen. Juga apically flat; median margins higher than tylus in profile. Ocelli placed on tubercles. Buccula sinuous, apical tooth acute, posterior lobe attaining the prosternum and obscuring first rostral segment laterally. Antennal segments: $\mathrm{I}<\mathrm{II}>\mathrm{III}<\mathrm{IV}<\mathrm{V}$. Humeral 

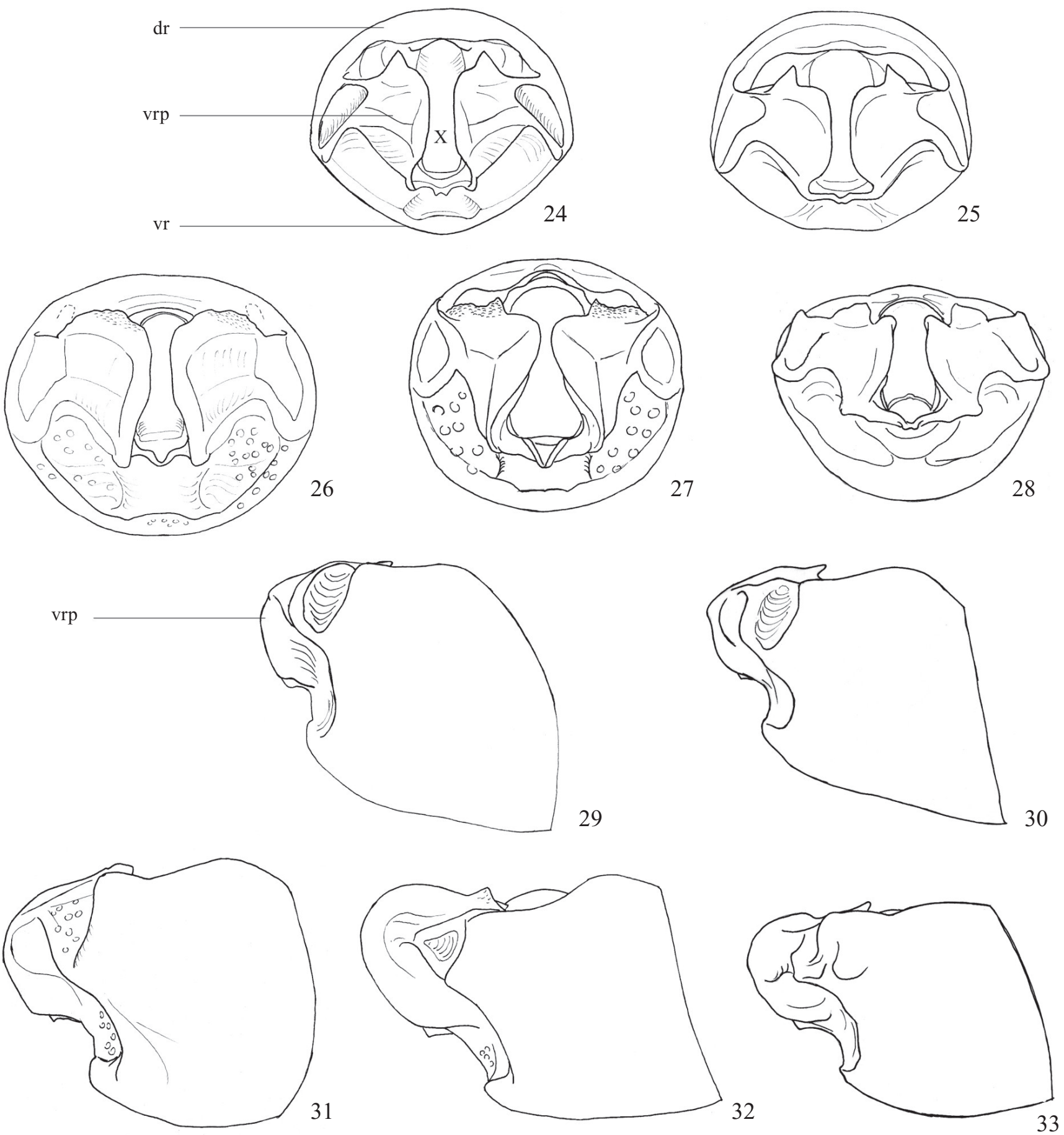

Figs. 24-33. Pygophore. 24-28. Posterior view: 24, Thoreyella paraiba sp. nov.; 25, T. cornuta; 26, T. maracaja sp. nov.; 27, T. brasiliensis; 28, T. trinotata; 29-33. Lateral view: 29, Thoreyella paraiba sp. nov.; 30, T. cornuta; 31, T. maracaja $\mathbf{s p . ~ n o v . ; ~ 3 2 , ~ T . ~ b r a s i l i e n s i s ; ~ 3 3 , ~ T . ~ t r i n o t a t a ; ~}(\mathrm{dr}=\mathrm{dorsal}$ rim; $\mathrm{vr}=$ ventral $\mathrm{rim} ; \mathrm{vrp}=$ ventral rim process; $\mathrm{X}=$ tenth segment $(\mathrm{Scale}=1 \mathrm{~mm})$.

angles developed in robust spines, apex obtuse, slightly directed anteroventrally. Pronotum slightly swollen between cicatrices. Scutellum almost as long as wide, apex rounded. Corium obscuring connexivum, hemelytra surpassing abdomen. Spines at apices of femur acute, short, less than one third the femur width, forming an angle with more than $45^{\circ}$. Abdominal spine broken (holotype). Spiracles not placed on a callus. Urosternites median sutures faint. Trichobothria placed laterally to the spiracles line. Posterior margin of segment VII in female (holotype) obscuring gonocoxites 8.

Female genitalia (Fig. 64). Laterotergites 8 concave at base, sutural margins swollen. Ventral band of laterotergites 8 twice larger than the X segment width. Gonocoxites 8 obovate without a cusp. Laterotergites 9 triangular, apex rounded slightly 

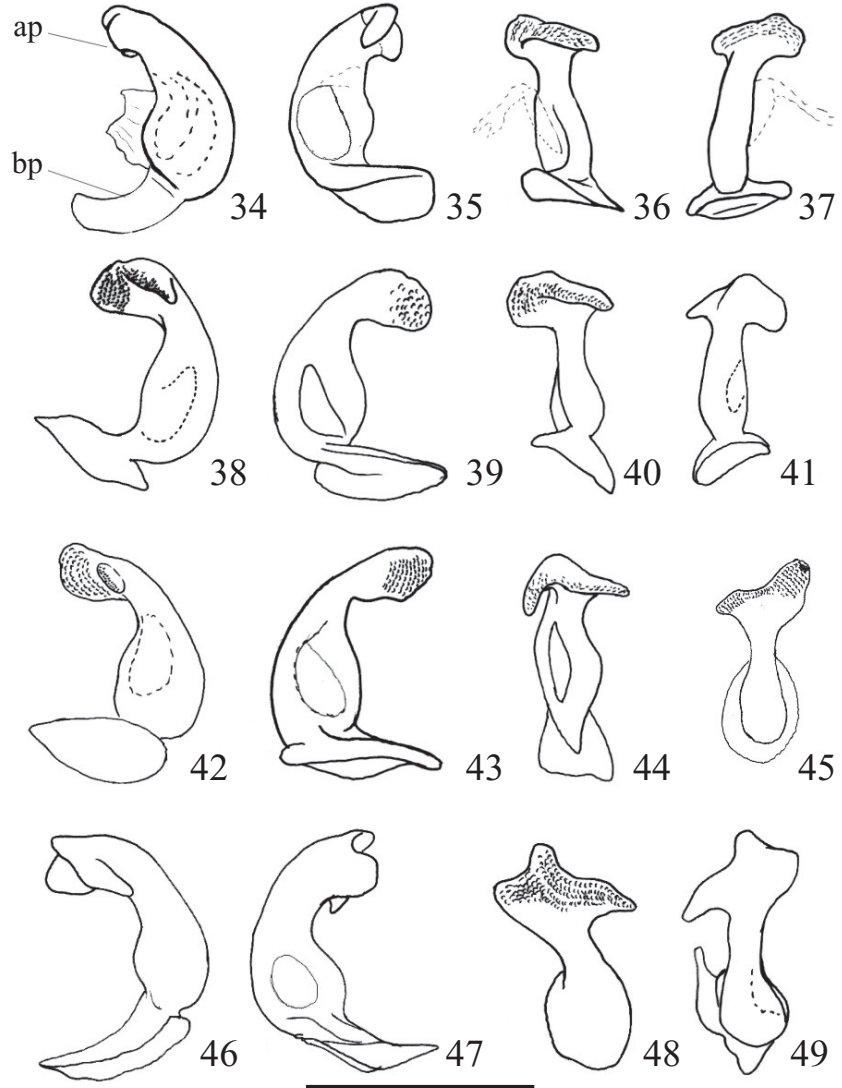

Figs. 34-49. Parameres, lateral, medial, dorsal, and ventral views. 34-37, Thoreyella cornuta; 38-41, T. maracaja $\mathbf{s p . ~ n o v . ; ~ 4 2 - 4 5 , ~ T . ~ b r a s i l i e n s i s ; ~}$ 46-49, T. trinotata. ap, apical portion; bp, basal portion. Scale $=0.5 \mathrm{~mm}$.

emarginated, lateral half slightly carinated, median half flat. Gonapophyses 8 medially constricted, rounded in each side of the faint longitudinal median suture. Segment X rectangular.

Measurements in Table I.

Distribution. BRAZIL: Minas Gerais.

Material examined. Holotype female, with the labels: a) Lagoa Santa, Reinhardt col. b) Jensen-Harupp Type Coll. c) ZMUC.

Comments. Thoreyella taurus shares with T. cornuta and T. paraiba sp. nov. the head darker than the body.

\section{Thoreyella maracaja sp. nov.}

(Figs. 5, 13, 16, 21, 26, 31, 38-41, 53-55, 65, 69, Table I)

Thoreyella sp.nov.1 in Bernardes et al., 2009: 2-4, 7, 9, 11-22.

Etymology. Allusive to the type-locality.

Diagnosis. Head triangular; lateral margins of juga outlined with black (Fig. 13). Humeral angles robust anteroventrally directed. Abdominal spine surpassing mesocoxae (Fig. 11). Spiracles placed on calli. Trichobothria tubercles black. Posterior margin of pygophore ventral rim processes with $1+1$ submarginal tooth not visible in posterior view of the pygophore (Fig. 26). Gonocoxites 8 reduced obovate, sutural and posterior borders convex, with a low cusp. Laterotergites 8 entirely concave.

Description. General color green, legs and antenna yellowish-brown. Punctures concolorous with the head. Lateral margins of juga outlined in black (Fig.13). Antenniferous tubercles with a longitudinal black line. Propleurum with two black macula. Humeral angles blackish by the presence of black punctures which are also present on posterior half of pronotum. Sternum concolorous with the body surface. Abdomen ventrally without macula, slightly darker along lateral margins. Abdominal spine dark on females. Spiracles calli white; bothrium black.

Ovate. Head with frons and vertex flat. Median margins of juga parallel along apical third, divergent before tylus. Buccula rectangular, apical tooth rounded. Antennal segments: $\mathrm{I}<\mathrm{II}<\mathrm{III}<\mathrm{IV}<\mathrm{V}$. Humeral angles with robust spines obliquely directed anteroventrally. Pronotum cicatrices well marked on posterior line; anterolateral margins concave smooth. Anterolateral pronotal spines short acute. Scutellum subtriangular (proportion 1:1) attaining abdominal segment VI (Fig. 5). Corium also attaining abdominal segment VI. Ostiolar ruga slightly curved anteriorly occupying half of metapleura. Evaporative area as long as ostiolar ruga and almost the same width. Mesopleural evaporative area occupying $3 / 4$ the ostiolar ruga length. Femur apical spine pointed, more developed on posterior legs, larger than half the width of femur (Fig. 10). Abdominal spine surpassing mesocoxa, apex curved inward (Fig. 11). Spiracles laterad to a callus (Fig. 11). Trichobothria placed on spiracles line. Posterolateral margins of segment VII convex. Posterior margin of segment VII, in females, obscuring gonocoxites 8 .

Male genitalia (Figs. 5, 13, 16, 21, 26, 31, 38-41, 5355). Pygophore. Process of the ventral rim with $1+1$ submarginal tooth, not visible in posterior view. Posterolateral angles oblique, concavity occupying a little less than the width of the ventral rim process. Parameres bilobate (Figs. 38-41) Phallotheca (Figs. 53-55) with postero-ventral opening; strongly convex dorsally, and slightly concave ventrally. Vesica slightly curved at base, strongly curved at apex, not surpassing the conjunctival lobes (Fig. 53). Secondary gonopore (Fig. 52) open ventrally.

Female genitalia (Figs. 65, 69). Laterotergites 8 entirely concave, with rounded apices. Gonocoxites 8 reduced obovate, slightly cuspidate, posterior and sutural margins convex. Laterotergites 9 triangular, lateral half slightly convex, median half flat, with a tiny concavity at posterior third. Gonapophyses 8 with a large concavity at middle, where the segment X fit; lateral margins roundish. Segment X trapezoidal, transversely striate. Pars intermedialis with less than half the length of the capsula seminalis. Posterior annular flange larger than anterior annular flange. Anterior portion of vesicular area curved, sclerotized, with constriction delimiting the posterior portion of vesicular area.

Measurements in Table I.

Distribution. BRAZIL: Minas Gerais, Santa Catarina, and Rio Grande do Sul. 
Material examined. Holotype male. BRAZIL. Santa Catarina: Maracajá, Parque Ecológico Maracajá, 16.I.2006, Bertolin, T. col., nº 001194 (CERSC). Paratypes. BRAZIL. Minas Gerais: Carmo do Rio Claro, I.1958, Carvalho \& Becker col., 1 male (UFRG); Santa Catarina: Maracajá, Parque Ecológico Maracajá, 27.VI.2006, T., Bertolin col., nº 001197, 1 female (CERSC); idem, $\mathrm{n}^{\circ}$ 001198, 1 female, (CERSC); idem, $\mathrm{n}^{\circ}$ 001196, 1 male (CERSC); idem, 21.VII.2006, n 001195, 1 male (CERSC); Rio Grande do Sul: Porto Alegre, 21.VIII.1929, n 235, unknown col., 1 male (UFRG).

Comments. The unique characters found in T. maracaja sp.nov. are trichobothria tubercles black and abdominal spine robust attaining mesocoxae. T. maracaja sp. nov. shares with T. brasiliensis the abdominal calli conspicuous, with $T$. trinotata the lateral margins of juga outlined in black, and with $T$. taurus the shape of the humeral angles.

\section{Thoreyella brasiliensis Spinola, 1850}

(Figs. 6, 17, 22, 27, 32, 42-45, 56-58, 66, 70, Table I)

Thoreyella brasiliensis Spinola, 1850: 80-81 (descr.); Spinola 1852: 120 121; Stål 1872: 45; Kirkaldy 1909: 137 (cat.); Buckup 1961: 13 (reg.); Rolston 1978: 22 (syn.); Rolston 1984: 828-830 (descr.); Rider 1994: 218 (citation); Grazia et. al. 1999: 109 (list); Grazia \& Schwertner 2008: 234 (list); Grazia \& Campos 2010 (lectotype des.); Bernardes et al. 2009: 3-15, 18, 20-22 (classification, distr., fig.); Grazia \& Schwertner 2011: 12 (list)

Rhaphigaster acutus Herrich-Schäffer, 1851: 318.

Uditta impicta Stål, 1860: 24

Odmalea olivacea Ruckes, 1959: 55.

Diagnosis. Juga strongly sinuous, continuous before tylus, with a quarter of the head length. Anterolateral margins of pronotum with one to eight acute teeth. Legs with black punctures. Spiracles placed on white calli. Pygophore ogival. Ventral rim processes long, about one third the length of the pygophore, with sutural margins convergent, well visible in profile. Posterior margins of the ventral rim processes with $3+3$ teeth, two of them flat, rhomboid at apex, adjacent to the parameres anteriorly directed; the other tooth smaller, wrinkled, with a crest on sutural margin, dorsad directed. Posterolateral margins of pygophore oblique, moderately excavated. Vesica long, less curved, with ventral opening. Laterotergites 8 with apex margin black.

Redescription. General color greenish-yellow, sometimes yellowish-brown to dark brown. Black punctures more concentrated on apex of juga, the remaining punctures concolorous with the dorsal surface of head. Lateral margins of juga, at apical third, outlined in black. Antenniferous tubercles with black dots dorsally. More concentrated black punctures on basal third of pronotum, including humeral angles, and apical third of scutellum. A black line on posterior surface of humeral angles, extending until mid of posterior margin. Propleurum with a black line. Legs brown or greenish, with black punctures. Spines at apices of femur apically black. Spiracles concolorous with the body surface, placed on white calli; trichobothria tubercles concolorous with the body.

Ovate and elongate (Fig. 6). Head with frons and vertex flat. Juga projected anteriorly, juga measuring more than half the length of buccula in lateral view. Juga concave at base
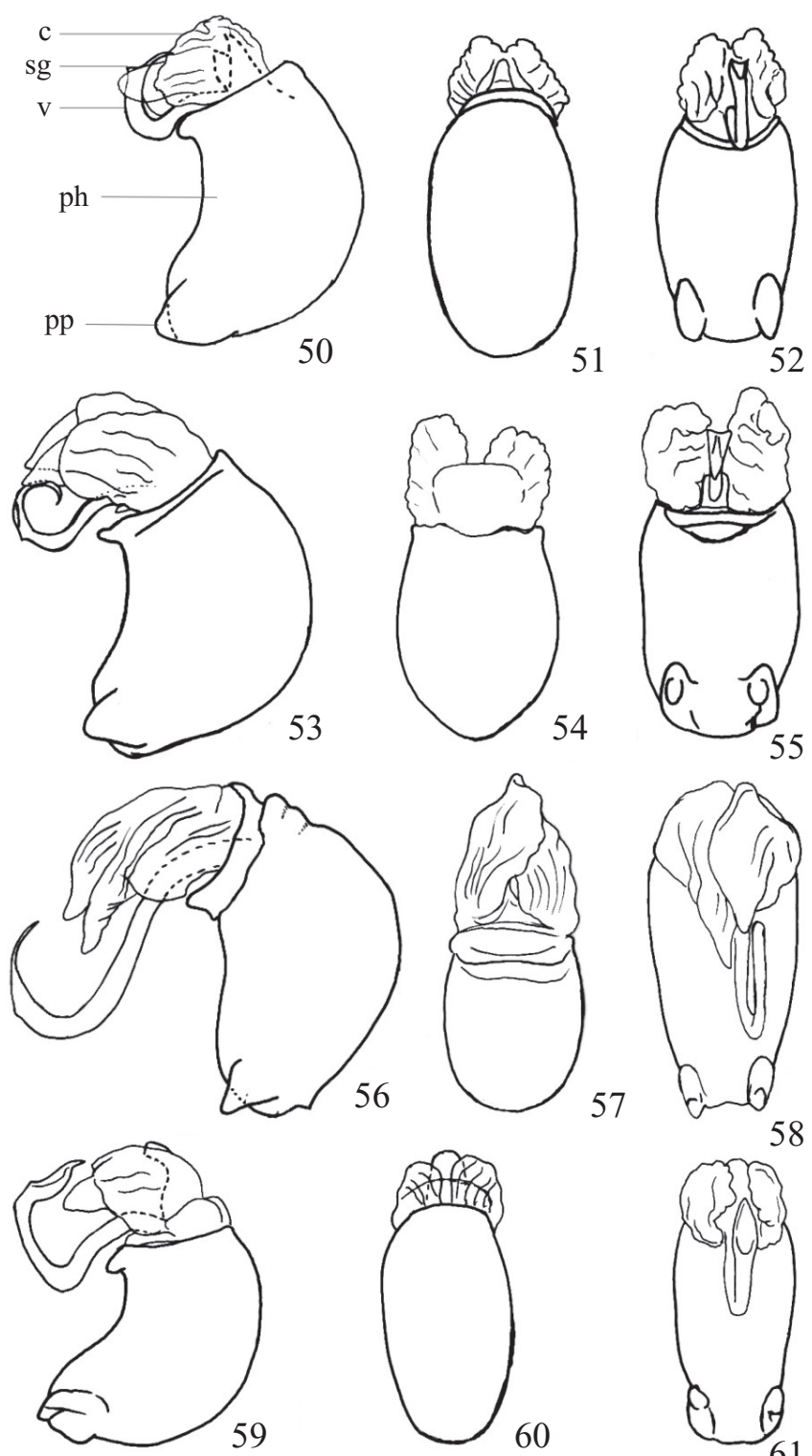

Figs. 50-61. Phallus, lateral, dorsal and ventral views. 50-52, Thoreyella cornuta; 53-55, T. maracaja sp. nov.; 56-58, T. brasiliensis; 59-61, T. trinotata. c, conjunctiva; ph, phallotheca; pp, processus phallothecae; sg, secondary gonopore; v, vesica. Scale $=0.5 \mathrm{~mm}$.

and slightly reflected at apical third. Ocelli placed on tubercles. Buccula rectangular, slightly sinuous, margins depressed obscuring the labium in profile; apical tooth directed anteriorly, not visible in lateral view; posterior lobe round, projected over protorax. Antennal segments: $\mathrm{I}<\mathrm{II}<\mathrm{III}<\mathrm{IV}<\mathrm{V}$. Pronotum sloping; humeral angles moderately developed in obtuse spines obliquely directed anteriorly. Anterior angles of pronotum with a round or acute spine. Pronotum cicatrices slightly swollen. Anterolateral margins of pronotum with one to eight acute or obtuse teeth (Fig. 6); posterolateral margins sinuous or rectilinear. Scutellum triangular (Fig. 9), longer than wide, spatulate at apex, surpassing corium and attaining the anterior margin of abdominal segment VII. Frenum reaching basal third of scutellum (Fig. 9). Apical spines 

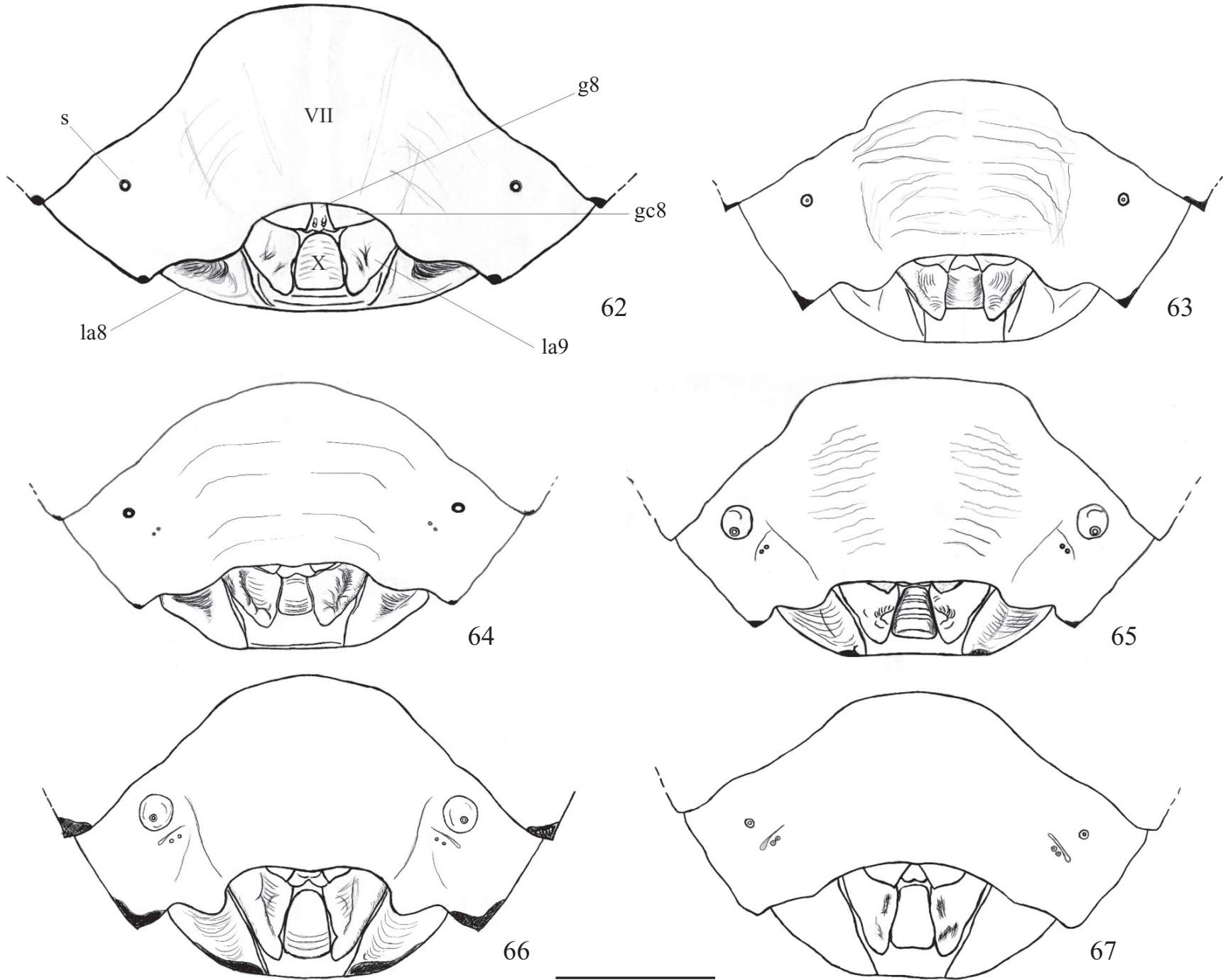

Figs. 62-67. Female genital plates, ventral view. 62, Thoreyella paraiba $\mathbf{s p . ~ n o v ; ~} 63$, T. cornuta; 64, T. taurus; 65 , T. maracaja sp. nov.; 66, T. brasiliensis 67, T. trinotata. gc8, gonocoxites 8; g8, gonapophyses 8; la8, laterotergites 8; la9, laterotergites 9; s, spiracle; VII, seventh abdominal segment; X, tenth segment. Scale $=1 \mathrm{~mm}$.

of femur little developed, less than half width of femur. Connexivum often exposed. Spiracles elevated by calli. Posterior margin of segment VII in females sinuous, partially obscuring the gonocoxites 8 .

Male genitalia (Figs. 6, 17, 22, 27, 32, 42-45, 56-58). Pygophore ogival. Ventral rim processes long, about one third the length of the pygophore, with sutural margins convergent, well visible in lateral view. Posterior margins of the ventral rim processes with $3+3$ teeth, two of them flat, rhomboid at apex, adjacent to the parameres and anteriorly directed; the other tooth smaller, wrinkled, with a crest on sutural margin, dorsally directed. Posterolateral margins of pygophore oblique, moderately excavated. Parameres bilobate (Figs. 42-45) with apical lobes almost forming a right angle in dorsal view. Phallotheca (Figs. 56-58) strongly convex dorsally, moderately concave ventrally, with postero-ventral opening. Secondary gonopore opening ventral. Vesica (Fig. 56) long, less curved, with ventral opening (Fig. 58), surpassing conjunctiva in approximately half of its length.

Female genitalia (Figs. 66, 70). Laterotergites 8 concave with black margins at apex (Fig. 66). Gonocoxites 8 triangular with a short cusp; sutural margins rectilinear; posterior margins sinuous adjacent to sutural margins, rectilinear toward the base. Laterotergites 9 with lateral half strongly convex, median half oblique, apex acute slightly emarginate. Gonapophyses 8 slightly concave at disk. Capsula seminalis globose with a long process measuring $4 / 5$ of its length (Fig. 70). Posterior annular flange (Fig. 70, paf) subequal the anterior annular flange (Fig. 70, aaf). Pars intermedialis with half length of capsula seminalis. Anterior portion of vesicular area slightly curved, sclerotized, occupying $1 / 3$ of the vesicular area length, with constriction delimiting posterior portion of vesicular area.

Measurements in Table I.

Distribution. BRAZIL: Mato Grosso [new record], Espírito Santo [new record], Minas Gerais, Rio de Janeiro, São 
Paulo, Paraná, Santa Catarina, and Rio Grande do Sul; ARGENTINA: Catamarca [new record], Misiones, Santa Fé, Córdoba [new record], and Buenos Aires.

Material examined. BRAZIL. Mato Grosso: Rosário Oeste, without data, 1 female (DZUP); Espírito Santo: Linhares, Parque de Sooretama, 18.X.1958, D. Zajclw col., 1 female (UFRG); Minas Gerais: Lavras, 29.I.2002, T. Cubiaki col., 1 female (DFLC); Perdizes, VII.1965. C. Elias col., 3 females (DZUP); Araxá, 27.X1965, C. Elias col., 1 female (DZUP); Alpinópolis 15-24.V.1963, Claudiomar Elias col., 1 female (DZUP); Poços de Caldas, Morro do ferro, 20.VII.1965, J. Becker, O. Roppa and O. Leoncini col., 1 female (MNRJ); Poço de Caldas, $\mathrm{M}^{\circ}$ S. Domingos, 29.II.1968. J. Becker, O. Roppa and O. Leoncini col., 2 females (MNRJ); Poços de Caldas, $\mathrm{M}^{\mathrm{o}} \mathrm{s}$. Domingos, 12.II.1969, J. Becker, O. Roppa \& O. Leoncini col., 1 male (MNRJ); Itajubá, 8.I.1961, Herbert col., 02103/61, 2 female, attached to the same pin (UFRG); São Paulo: São Roque, 14.VI.1949, F. Lane col., 1 male (UFRG); São José do Barreiro, Sa. Bocaina-1500m, 4.XI.1965, F.M. Oliveira col., 2 males 3 females (DZUP); São Paulo, Est. Carlos Norberto, 800ms., 21.X.1942, L. Trav. \& Almeida col., n 02564, 1 female (FIOC); Campos do Jordão, Eug. Lefevre: 1200m, 24.I.1963, J. Guimarães, Medeiros, L. Silva, A. Rocha \& L. T. F. col., 1 male, 1 female (UFRG); Cantareira, Bairro S. Paulo, Museu Dirings, XI.1936, Dirings col. 111, 1 female (MZSP); Parelheiros, 20.XII.1975, L.R. Fontes col., 1 female (UFRG); Ipiranga, 18.XII.1961, Trigo \& Batista col., 1 female (UFRG); Paraná: no data, J.C.M. Carvalho col., 1 female (UFRG); Curitiba, IX.1961, S. Laroca col., 1 male (DZUP); Curitiba, 16.II.1966, C. Ext. D.Z.U.F.P. col., 1 male (DZUP); Curitiba, 4.IV.1967, D.Z.U.F.P. col., 1 female (DZUP); Ponta Grossa, Pedreira, 1735, X.1942, unknown col., 1 male, 1 female (DZUP); Ponta Grossa, 1731, 1942, unknown col., 1 female (DZUP); Ponta Grossa, XII.1938, Camargo col., 1 female (UFRG); São Mateus do Sul, 3.XI.1982, Iede col., 1 male (UFRG); Londrina, 26.III.1997, Clarice col., 1 male (UFRG); Pinhão, Rio Bragança, 26.X.1991, R. P. da Rocha col., 2 females (UFRG); Santa Catarina: Mafra XII.1959, unknown col., 1 male, 1 female (UFRG); Rio Vermelho, III.1953, Dirings col., 1 male, 1 female (MZSP); Nova Teutônia, $27^{\circ} 11^{\prime} 8,52^{\circ} 23^{\prime}, 300 \mathrm{~m}$, 16.VII.1948, Fritz Plaumann col., Ex. Coll. H. Ruckes, 1 male (UFRG); Nova Teutônia, $27^{\circ} 11^{\prime} 8,52^{\circ} 23^{\prime}$, 300-500 m, 12.I.1949, 1 male (UFRG); Cauna, 11.X.1945, A. Maller col. Frank Johnson Donor, 1 male (UFRG); Rio Grande do Sul: Bom Jesus, XII.1954, Baucke col., 3 females, 1 male (UFRG); Bom Jesus, I.1955, Corseuil col., 2 females (UFRG); Vila Oliva, II.1950, 5 females, 1 male (UFRG); Catuípe, 17.XI.2004, F.L. Santos col., n 5525, 1 male (Laboratório de Zoologia, UNIJUÍ); idem, data 30.I.2005, n 5838,1 female (Laboratório de Zoologia, UNIJUÍ); idem, $\mathrm{n}^{\circ}$ 5840, 1 male (Laboratório de Zoologia, UNIJUÍ); idem, n 5941, 1 male (Laboratório de Zoologia, UNIJUÍ); idem, $\mathrm{n}^{\circ}$ 5839, 1 female (UFRG); idem, $\mathrm{n}^{\circ} 5842,1$ male (UFRG); Rio Grande, E. E. do Taim, 23.III.-3.IV.1981, J. Grazia col., 1 female (UFRG); idem, 11.III.1982, 1 female (UFRG); idem, 13.III.1982, 1 female (UFRG); idem 14.III.1982, 1 female (UFRG); idem, 15.III.1982, 1 female (UFRG). ARGENTINA. Buenos Aires: Delta, 13.X.1946, Bachmann col., 1 male (MACN); San Fernando, without data, 1 male, 1 female (MACN); Corrientes: San Tomé X.1925, unknown col., 1 female, 1 male (MACN); Misiones: Loreto, III.1936, unknown col., 1 male (MACN); Iguazú, 30.I13.III.1945, Hayward col., 1 male (RMNH); Catamarca: El Rodeo, 1500m, 8-28.I.1958, R. Globach col., 4 females (RMNH); Córdoba. Almafuerte, La Cascada, III.1964, F.H. Waltz col., 1 male (RMNH).

Comments. Juga are longer and wider than in remaining species of Thoreyella. The anterolateral margins of pronotum with one to eight acute teeth and the black punctures on legs are autapomorphies to T. brasiliensis. Spiracles elevated by calli is shared with T. maracaja sp. nov., however the position of the spiracles on calli are distinct: in T. brasiliensis the spiracles are on the center of the calli, and in T. maracaja sp. nov. the spiracles are laterad. Also, the angle formed by the lobes of the parameres is distinct of the remaining species.

\section{Thoreyella trinotata Berg, 1878}

(Figs. 7, 18, 23, 28, 33, 46-49, 59-61, 67, 71, Table I)

Thoreyella trinotata Berg, 1878: 27 (descr.); Berg 1879: 58 (citation); Berg 1883: 214; Berg 1884: 30 (reprint); Kirkaldy 1909: 137 (cat.); Rolston 1984: 832-833 (descr.); Rider 1994: 218 (citation); Coscarón \& Grazia 1996: 109 (cat.); Grazia \& Schwertner 2008: 234 (list); Bernardes et al. 2009: 3, 4, 7, 8, 10-12, 14, 15, 18, 20-22 (classification, distr., fig.).

Diagnosis. Juga inconspicuously sinuous, lateral margins outlined in black. Head flat, with greenish- to light-brown punctures. Pair of black stripes extending from base of eyes through antenniferous tubercles reaching half of juga. Propleurum with black line. Spiracles not placed on calli. Posterior margins of the ventral rim processes of pygophore sulcate, inferior margin of sulcus more pronounced than the superior. Posterior margin of urosternite VII in females, trapezoidal; laterotergites 8 entirely flat.

Redescription. General color greenish- to light-brown on head and body. Juga with lateral margins outlined in black. Pair of black stripes extending from the base of eyes through antenniferous tubercles reaching half of juga. Pronotum punctures concolorous with body surface. Humeral angles spines with black line on posterolateral angles. Scutellum with black dot at apex of clavus; sometimes the apex of scutellum is outlined in black. Dark stripe on posterior margin of corium is present in some specimens. Propleurum with black line. Mesopleurum immaculate. Posterolateral angles of urosternites immaculate. Spiracles concolorous with body surface.

Elongate (Fig. 7). Head subtriangular, frons and vertex flat. Margins of juga almost rectilinear before the eyes. Dorsal surface of tylus compressed, at the same level of juga. Anterior tooth of buccula obtuse, discrete. Lateral spine of antenniferous tubercle rounded. Antennal segments: I $<$ II $>$ III $<$ IV $<$ V. Humeral angles with spines varying from small to well developed, directed laterad. Scutellum triangular, longer than wide, reaching apices of corium; median longitudinal calloused line covering at least anterior $2 / 3$ of scutellum. Frenum reaching basal third of scutellum. Sutural margins of corium well defined. Ostiolar ruga not differentiated, attached to the tegument of metapleurum. Spines at apices of femur short, three times shorter than the width of femur, with an angle larger than $45^{\circ}$. Fore tibia dorsally flat. Spiracles not placed on calli. Posterior margin of segment VII, in females, trapezoidal.

Male genitalia (Figs. 7, 18, 23, 28, 33, 46-49, 59-61). Ventral rim processes of pygophore robust, sutural margins parallel. Posterior margins of the ventral rim processes sulcate, inferior margin of sulcus more pronounced than the superior. Concavity at posterolateral angles of pygophore shallow. Parameres trilobate. Basal portion of parameres flat, wider than the apical portion. Vesica long, hook-like (Fig. 59) surpassing conjunctiva and reaching ventral surface of phallotheca (Fig. 61). Phallotheca opening posteriorly. Secondary gonopore opening posteriorly. 

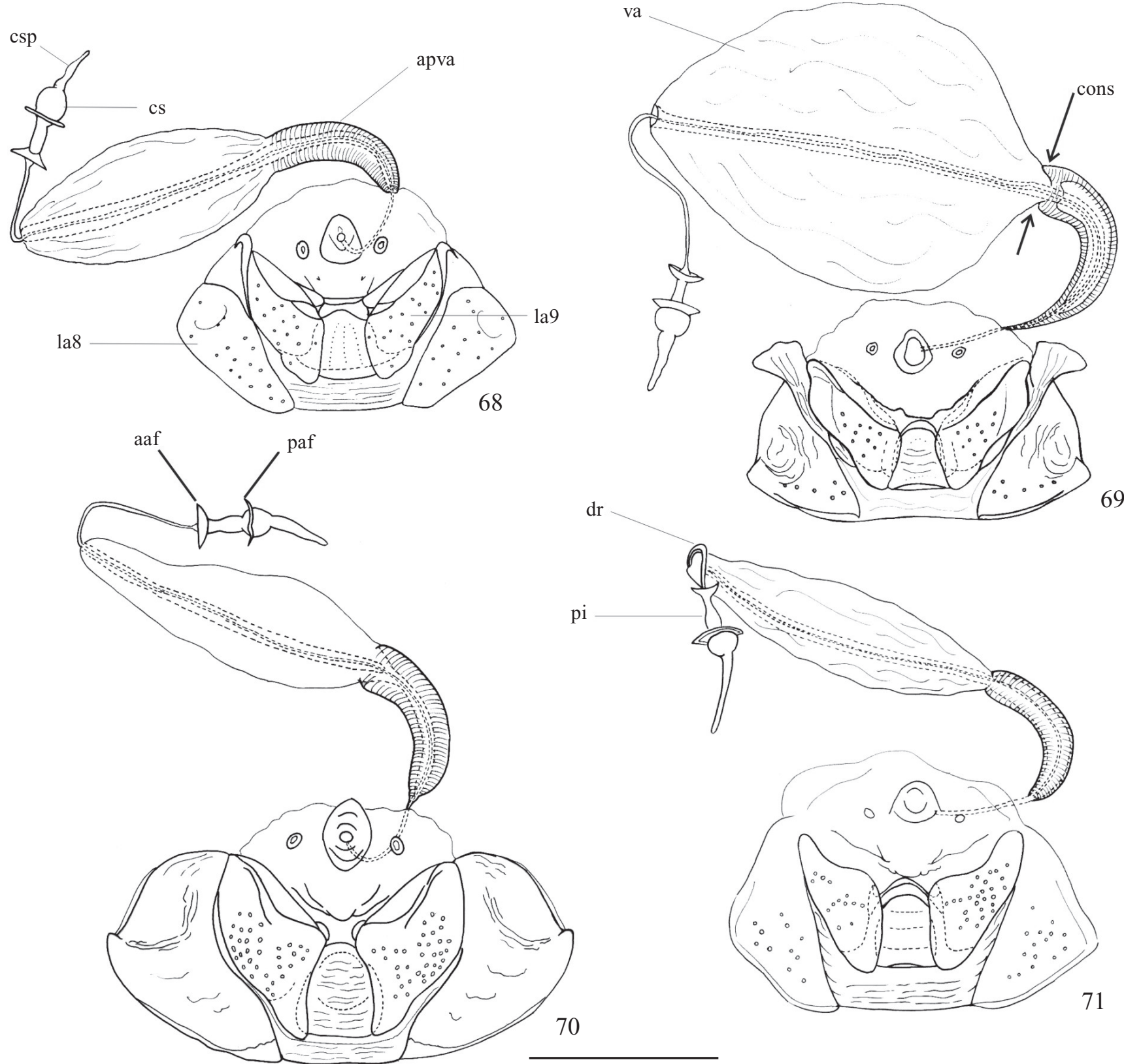

$\mathrm{dr}$

Figs. 68-71. Ectodermal ducts and laterotergites, gonocoxites and gonapophyses of the female ninth segment. 68, Thoreyella cornuta; 69, T. maracaja sp. nov.; 70, T. brasiliensis; 71, T. trinotata. aaf, anterior annular flange; apva, anterior portion of vesicular area; cons, constriction; cs, capsula seminalis; csp, capsula seminalis process; dr, ductus receptaculi; la8, laterotergite 8; la9, laterotergite 9; paf, posterior annular flange; pi, pars intermedialis; va, vesicular area of ductus seminis. Scale $=1 \mathrm{~mm}$.

Female genitalia (Figs. 67, 71). Laterotergites 8 entirely flat. Gonocoxites 8 triangular, with moderate cusp; posterior margins sinuous, depressed, and translucid, shallowly concave adjacent the cusp, remaining surface convex; sutural margins rectilinear. Laterotergites 9 with lateral half strongly convex, median half oblique. Gonapophyses 8 with surface flat with a median crest; posterior margin convex medially. Capsula seminalis process long and tapered, occupying 4/5 of its length. Capsula seminalis three times larger than pars intermedialis (Fig. 71, pi); posterior annular flange smaller than anterior annular flange.
Distribution: BRAZIL [new record]: Rio Grande do Sul; PARAGUAY [Rolston (1984)]; URUGUAY; ARGENTINA: Missiones, Formosa, Santa Fé, and Buenos Aires.

Material examined. Holotype male, with the labels: a) typus, b) Buenos Aires, c) 1411, d) MLPA e) Lectotype Thoreyella trinotata Berg. Paratypes. ARGENTINA. Buenos Aires, no data, Typus, Baradero, F. Lynch col., ${ }^{\circ}$ 1411, 1 female (MLPA); Buenos Aires, no data, Typus, $n^{\circ} 1411,2$ females (MLPA). BRAZIL. Rio Grande do Sul: Rio Grande, Est. Ecol. Taim, 11.III.1982, J. Grazia col., 2 males, 1 female (UFRG); idem, 13.III.1982, 1 female (UFRG); idem, 14.III.1982, 2 males, 3 females (UFRG); idem, 15.III.1982, 1 female (UFRG); idem, 16.III.1982, 3 males, 2 females (UFRG); idem, 18.III.1982, 2 males, 1 female (UFRG); idem, 30.III.1982, 
1 male (UFRG). URUGUAY. Banda Oriental, "cum typo comparat", no data, 2 females (MLPA). ARGENTINA. Misiones: Leandro N. Alem, XI.1956, A. Martinez col., 1 female (UFRG); Formosa: La Florência Este, 1-6.XII.1949, Momros col., Ins. M. Lillo, 1 male (UFRG); Santa Fé: Rosário, no data, 1 female (MACN); Buenos Aires: Tigre, no data, 1 female (MACN); Veronica FCS, no data, J.B.Daguerra col., 1 male, 1 female (MACN); no data, 6.X.1896, n 5653, S. Venturi col., 1 female (MACN); idem, 15.X.1896, 1 male (MACN); idem, 19.X.1896, 1 male (MACN); Buenos Aires, "cum typo comparat", Günther col., N 11949, 1 female (MACN); Buenos Aires Ciudad, 27.II.1912, Bosq, 1 male (MLPA); Belgrano, 7.II.1917, Bosq 1942, 1 female (MLPA).

Comments. Lateral margins of juga outlined in black is shared with $T$. maracaja sp. nov. Humeral angles spines varies in length, from small to well developed, acute and directed laterad. The scutellum is thinner than in the remaining species. Specimens recently collected have a pale, translucid green color.

\section{ACKNOWLEDGMENTS}

The authors wish to thank the curators for the loan of specimens used in this study. To the anonymous referees for suggestions to improve the manuscript. To Cassandra Monteiro, Augusto Ferrari and Luciana Maria Weiler for the help with the illustrations. To CNPq (JG), and CNPq/CAPESPROTAX (JLCB and CFS) for fellowships to the authors.

\section{REFERENCES}

Berg, C. 1878. Hemiptera Argentina: Ensayo de uma monografia de los Hemípteros Heteropteros y Homópteros da la Republica Argentina. Anales de la Sociedad Científica Argentina 6: 23-32.

Berg, C. 1879. Hemiptera Argentina enumeravit speciesque novas descriptsi. Bonariae, viii $+316 \mathrm{p}$.

Berg, C. 1883. Addenda et emendanda ad Hemiptera Argentina. Anales de la Sociedad Científica Argentina 15: 193-217.

Berg, C. 1884. Addenda et emendanda ad Hemiptera Argentina. Bonarie, 213p. (reprint).

Bernardes, J. L. C.; C. F. Schwertner \& J. Grazia. 2009. Cladistic analysis of Thoreyella and related genera (Hemiptera: Pentatomidae: Pentatominae: Procleticini). Zootaxa 2310: 1-23.

Buckup, L. 1961. Os pentatomídeos do estado do Rio Grande do Sul (Brasil) (Hemiptera-Hetroptera-Pentatomidae). Iheringia, Série Zoologia 16: $5-23$.

Coscarón, M. C. del \& J. Grazia. 1996. Los ejemplares tipo de Pentatomidae (Heteroptera) depositados en la coleción del Museo de La Plata. Serie Técnica y Didática Museo de La Plata 36: 21-27.

Davidová-Vilímová, J. \& J. E. McPherson. 1991. Pygophores of selected species of Pentatomoidea (Heteroptera) from Illinois. Acta Universitatis Carolinae. Biologica 35: 143-183.

Dupuis, C. 1970. Heteroptera, p. 190-208. In: S. L. Tuxen(ed.) Taxonomist's glossary of genitalia of insects. Munksgaard-Copenhagen.
Grazia, J. \& C. F. Schwertner. 2008. Pentatomidae y Cyrtocoridae. In: Debandi, G.; L. Claps \& S. Roig-Juñent (eds.). Biodiversidad de artrópodos argentinos. vol. 2, Tucúman, SEA, 599 p.

Grazi, J. \& C.F. Schwertner. 2011. Check-list dos percevejos-do-mato (Hemiptera: Heteroptera: Pentatomoidea) do Estado de São Paulo, Brasil. Biota Neotropica 11: 1-12. Available from: http://www.biotaneotropica. org.br/v11n1a/pt/fullpaper?bn0371101a2011+pt (accessed 3 August 2011)

Grazia, J. \& L. A. Campos. 2010. Neotropical Pentatomidae (Insecta: Hemiptera: Heteroptera) of the collection of Massimiliano Spinola preserved in the "Museo Regionale de Scienze Naturali", Turin. Zoologia 27: 413-424.

Grazia, J.; N. D. F. De Fortes \& L. A. Campos. 1999. Superfamília Pentatomoidea, p. 101-112. In: Brandão, L.R. \& E. Cancello (eds.). Biodiversidade do Estado de São Paulo, Brasil: síntese do conhecimento ao final do século XX, vol. 5, São Paulo, FAPESP, xviii+279 p.

Herrich-Schäffer, G. A. H. 1851. Die Wanzenartigen Insecten. vol. 9, Nurberg, 348 p.

Jensen-Haarup, W. C. 1931. Hemipterological notes and descriptions VI. Entomologiske Meddelelser Udgivne af Entomologisk Forening 17: 319-336.

Kirkaldy, G. W. 1909. Catalogue of the Hemiptera (Heteroptera). 1.Cimicidae. Berlin, Felix L. Dames, xi+392 p.

Pirán, A. A. 1956. Hemipteros raros o poco conocidos y no mencionados par alas faunas de Brasil, Uruguay, Argentina, Paraguay y Bolivia. Revista de la Sociedad Uruguaya de Entomologia 1: 29-35.

Pirán, A. A. 1957. Thoreyella pentamaculata especie nueva de la fauna de Bolivia (Hemiptera, Pentatomidae). Neotropica 2: 65-68.

Rider, D. A. 1994. A generic conspectus of the tribe Procleticini Pennington (Heteroptera, Pentatomidae), with the description of Paraodmalea rubella, new genus and species. Journal of the New York Entomological Society 102: 193-221.

Rolston, L. H. 1978. A revision of the genus Odmalea Bergroth (Hemiptera: Pentatomidae). Journal of the New York Entomological Society 86: 20-36.

Rolston, L. H. 1984. A review of the genus Thoreyella Spinola (Hemiptera: Pentatomidae). Proceedings of the Entomological Society of Washington 86: 826-834.

Rolston, L. H.; F. J. D. Mcdonald \& D. B. Thomas Jr. 1980. A conspectus of Pentatomini genera of the Western Hemisphere - Part 1 (Hemiptera: Pentatomidae). Journal of the New York Entomological Society 88 : $120-132$.

Ruckes, H. 1959. A new species of Odmalea Bergroth from Brazil. Journal of the New York Entomological Society 67: 55-57.

Schaefer, C. W. 1977. Genital capsule of the trichophoran male (Hemiptera: Heteroptera: Geocorisae). International Journal of Insect Morphology \& Embryology 6: 277-301.

Stål, C. 1860. Bidrag till Rio Janeiro- traktens Hemipterfauna. Kongliga Svenska Vetenskaps-Akademiens Handlingar 2: 1-84.

Stål, C. 1867. Bidrag till Hemipterernas Systematik. Öfversigt af Kongliga Vetenskaps-Akademiens Förhandlingar 24: 491-534.

Stål, C. 1872. Enumeratio Hemipterorum II. Kongliga Svenska VetenskapsAkademiens Handlingar 10: 1-159.

Spinola, M. 1850. Di alcuni generi d'insetti arthroidignati nouvamenti proposit. Modena, p. 61-138.

Spinola, M. 1852. Di alcuni generi d'insetti arthroidignati nuovamente proposti. Memorie di Matematica e di Fisica della Società italiana delle Scienze Modena 25: 101-178. 